\title{
Timing of nutrient restriction and programming of fetal adipose tissue development
}

\author{
Michael E. Symonds, Sarah Pearce, Jayson Bispham, David S. Gardner and Terence Stephenson \\ Centre for Reproduction and Early Life, Institute of Clinical Research, Queen's Medical Centre, University Hospital, \\ Nottingham NG7 2UH, UK
}

\begin{abstract}
It is apparent from epidemiological studies that the timing of maternal nutrient restriction has a major influence on outcome in terms of predisposing the resulting offspring to adult obesity. The present review will consider the extent to which maternal age, parity and nutritional restriction at defined stages of gestation can have important effects on fat deposition and endocrine sensitivity of adipose tissue in the offspring. For example, in 1-year-old sheep the offspring of juvenile mothers have substantially reduced fat deposition compared with those born to adult mothers. Offspring of primiparous adult mothers, however, show increased adiposity compared with those born to multiparous mothers. These offspring of multiparous ewes show retained abundance of the brown adipose tissue-specific uncoupling protein 1 at 1 month of age. A stimulated rate of metabolism in brown fat of these offspring may act to reduce adipose tissue deposition in later life. In terms of defined windows of development that can programme adipose tissue growth, maternal nutrient restriction targetted over the period of maximal placental growth results in increased adiposity at term in conjunction with enhanced abundance of mRNA for the insulin-like growth factor-I and -II receptors. In contrast, nutrient restriction in late gestation, coincident with the period of maximal fetal growth, has no major effect on adiposity but results in greater abundance of specific mitochondrial proteins, i.e. voltage-dependent anion channel and/or uncoupling protein 2. These adaptations may increase the predisposal of these offspring to adult obesity. Increasing maternal nutrition in late gestation, however, can result in proportionately less fetal adipose tissue deposition in conjunction with enhanced abundance of uncoupling protein 1 .
\end{abstract}

Maternal nutrient restriction: Fetal adipose tissue development: Endocrine sensitivity: Adult obesity

Adipose tissue is laid down early in fetal life, and during normal development there appears to be distinct lineages of white and brown adipocytes (Moulin et al. 2001). Fetal fat exhibits brown and white characteristics, demonstrating an ontogenic increase in the brown adipose tissue-specific uncoupling protein (UCP) 1 (Clarke et al. 1997a) together with a more modest rise in leptin synthesis (Yuen et al. 1999), a product primarily of white adipocytes. Fetal adipose tissue is made up of a combination of multilocular and unilocular cells (Yuen et al. 2003), of which the latter possess few, if any, mitochondria. However, their proportional abundance increases after birth as white adipose tissue dominates (Gemmel et al. 1972). Following birth, which results in substantial endocrine stimulation of UCP1 synthesis (Symonds et al. 2003), there is normally a gradual loss of UCP1 to undetectable levels at 1 month of age in sheep (Mostyn et al. 2003). The decline in UCP1 is paralleled by a gradual rise in plasma leptin and mRNA for leptin up to 1 week after birth (Bispham et al. 2002). The increase in adipose tissue deposition after 1 week occurs independently of any change in leptin. These adaptations represent a major transition that has pronounced implications for future adipose tissue development. The magnitude of these and subsequent changes within fat are determined by the maternal, and therefore fetal, nutritional environment. As a consequence modest perturbations in fetal adipose tissue growth and endocrine sensitivity can have very-long-term outcomes. In the present review the extent to which maternal age, parity and nutritional restriction at defined stages of gestation can have important effects on fat deposition and endocrine sensitivity of adipose tissue in the resulting offspring will be considered.

Abbreviations: IGF, insulin-like growth factors; UCP, uncoupling protein.

Corresponding author: Dr Michael E. Symonds, fax +44 115970 9382, email Michael.Symonds@nottingham.ac.uk 


\section{Ontogeny of fetal and postnatal adipose tissue development}

From very early in fetal development adipose tissue is present, and in the sheep the most abundant site is the perirenal-abdominal region, which comprises approximately $80 \%$ of the total fat stores (Clarke et al. 1997a). At $90 \mathrm{~d}$ gestation (term $147 \mathrm{~d}$ ), when only 1-2 g adipose tissue are laid down, the first expression of mRNA for both UCP1 and leptin occurs (Yuen et al. 1999; Budge et al. 2004). There is then a gradual increase in the mRNA and/or protein for UCP1 and leptin, plus endocrine growth factors, up to term. This process is accompanied by increased plasma concentrations of a range of endocrine stimulatory factors, including triiodothyronine, noradrenaline, cortisol, prolactin and insulin-like growth factors (IGF), in parallel with an up-regulation of respective receptor populations (Symonds et al. 2003). These factors are all important in promoting adipose tissue deposition and ensuring UCP1 abundance is maximal around the time of birth. The abundance of some of these receptors continues to rise during postnatal life (e.g. IGF) and may be important in ensuring sufficient fat depots are laid down after birth. For example, a large increase in adipose tissue growth occurs over the first week of life (Bispham et al. 2002). The nutritional signal for this adaptation is likely to be abundant milk supply from the mother, which has a high fat content (Clarke et al. 1997b). Between 2 and $4 \mathrm{~d}$ after birth an approximately tenfold increase in mRNA for both IGF-I and -II receptors (Bispham et al. 2003a) is coincident with a doubling of adipose tissue mass, indicating the potential importance that IGF may play in promoting fat growth (Fig. 1).

\section{The timing of maternal nutrient restriction and subsequent effects on fetal adiposity}

\section{Nutrient restriction between early and mid gestation}

One of the most striking epidemiological findings relating to the timing of maternal nutrient restriction and subsequent predisposal to adult obesity comes from the Dutch famine of 1944-5. During the 5-month period of the famine mean energy intake was $3.2 \mathrm{MJ} / \mathrm{d}$ compared with $6.3 \mathrm{MJ} / \mathrm{d}$ immediately afterwards (Roseboom, 2000). Dietary restriction during early gestation was shown to have the greatest effect on placental size:birth weight and to result in a much greater risk of adult $\mathrm{CHD}$ and obesity (Roseboom et al. $2000 a, b)$. It is interesting to note that when using sheep models of undernutrition that broadly adopt the same magnitude of nutrient restriction as that imposed under the Dutch famine there is seldom any effect on birth weight but a pronounced effect on placental mass (Dandrea et al. 2001). The consistent finding that a $50 \%$ variation in maternal food intake can determine placental mass may have further relevance to contemporary human populations, for which a similar range between the upper and lower quartiles in energy intake is found in both early and late gestation (Godfrey et al. 1996).

It has now been established that maternal, and therefore fetal, nutrition are primary regulators of fetal adipose tissue
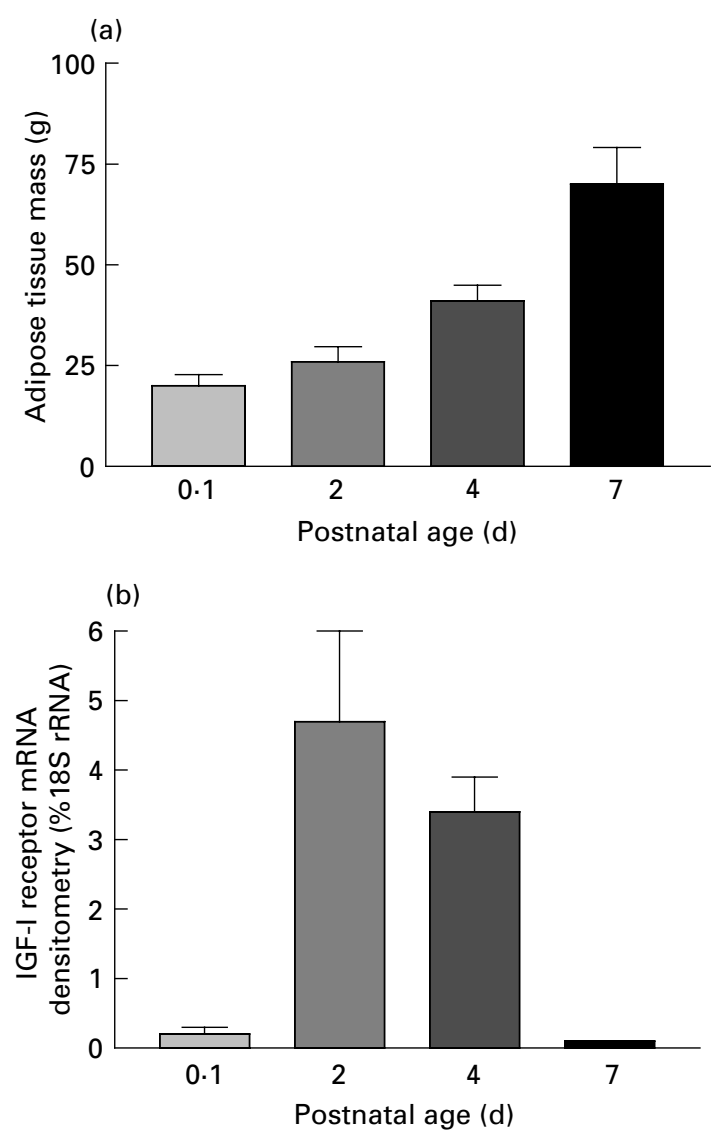

Fig. 1. Summary of the relationship between adipose tissue growth (a) and insulin-like growth factor (IGF)-I receptor mRNA abundance (b) in the postnatal lamb. Total perirenal adipose tissue was sampled from young sheep at each age. mRNA abundance for each receptor was then determined as described by Bispham et al. (2003b). Values are means with their standard errors represented by vertical bars for four to five sheep per age-group. (Adapted from Bispham et al. 2003a.)

deposition and hormone receptor mRNA abundance, particularly when nutrient restriction is targetted over the period of maximal placental growth (Bispham et al. 2003b). In terms of the impact of maternal nutritional manipulation on the fetus, the consequences for adipose tissue deposition are strongly dependent on the time of the nutritional intervention. For sheep, nutrient restriction up to $110 \mathrm{~d}$ gestation promotes adipose tissue deposition (Gopalakrishnan et al. 2001), whereas nutrient restriction after this time decreases it (Fig. 2). Then, following the restoration of the maternal diet to the same level as controls, after at least $80 \mathrm{~d}$ gestation, a further stimulus for fat deposition occurs (Bispham et al. 2003b). This adaptation is accompanied by an increased abundance of mRNA for IGF-I and -II receptors, which is likely to increase adipose tissue sensitivity to the potential anabolic effects of IGF (Teruel et al. 1996). A combination of enhanced responsiveness to IGF in conjunction with increased abundance of GLUT1 in fetuses that have been previously nutrient restricted (Dandrea et al. 2001) may act to promote the anabolic effect of glucose on fetal fat growth (Stevens et al. 1990). 

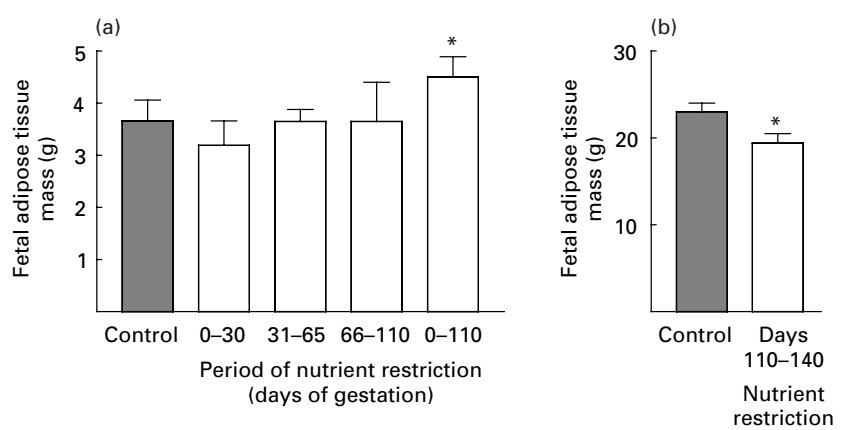

Fig. 2. Effect of the timing of maternal nutrient restriction on fetal adipose tissue mass in the ovine fetus. The magnitude of maternal nutrient restriction was $50 \%$ of total metabolisable energy requirements for that stage of gestation (see Symonds et al. 1998) and all animals were fed to $100 \%$ of requirements for the remainder of gestation. Values are means with their standard errors represented by vertical bars. Mean values were significantly different from control values: ${ }^{\star} P<0 \cdot 05$. (Adapted from Gopalakrishnan et al. 2001 and Symonds et al. 1998.)

In summary, prolonged (i.e. $>30 \mathrm{~d}$ ) maternal nutrient restriction up to $80-110 \mathrm{~d}$ gestation results in enhanced fetal fat deposition. This increase occurs in combination with enhanced IGF receptor abundance and glucose supply, which may exacerbate the deposition of fat following the restoration of the maternal diet (Bispham et al. 2003b).

\section{Maternal nutrient restriction, insulin-like growth factors, glucocorticoids and adiposity}

The enhanced adipose tissue deposition following reduced maternal nutrition between early and mid gestation provides further evidence that fetal adiposity can be programmed in utero. The findings suggest that the increased incidence of obesity in adults born to mothers exposed to the Dutch famine during early pregnancy (Roseboom et al. $2000 a$ ) may be a direct consequence of adaptations in the endocrine sensitivity of fetal adipose tissue.

In both sheep and man the majority of fetal adipose tissue is deposited during the final third of gestation (Symonds \& Lomax, 1992). Over this period there is an increased abundance within the fetal circulation of hormones that are important in regulating fetal adipose tissue growth (Symonds \& Stephenson, 1999), including IGF-I and leptin (Lorenzo et al. 1993; Yuen et al. 1999). The extent to which mRNA abundance within adipose tissue is increased or decreased at term during or following nutritional manipulation is determined by the level of maternal nutrition throughout gestation. In vitro, IGF-I has been shown to have an anabolic effect on fetal adipose tissue growth (Lorenzo et al. 1993). The fetal plasma concentration of IGF-I is normally positively related to fetal glucose supply (Owens et al. 1994). An increase in nutrient supply to the fetus may also contribute to greater mRNA abundance for the receptor, thereby increasing tissue sensitivity to IGF-I. As a consequence, IGF-I may have an anabolic effect on the growth of specific tissues in the absence of a marked change in plasma concentration. This effect may also explain the loss of the relationship normally seen between fetal dimensions and organ weights at term and plasma IGF-I, which has previously been described in nutrient-restricted offspring (Heasman et al. 2000). Fetal overgrowth following in vitro fertilisation is associated with a reduction in IGF-II receptor mRNA abundance in a range of fetal tissues, including the liver, kidney, heart and muscle (Young et al. 2001), although fat has not been investigated. It has been suggested, therefore, that reduced abundance of the IGF-II receptor acts to remove some of the fetal constraints on growth; however, it is not known whether this action extends to adipose tissue growth. These findings, therefore, indicate that although IGF-I and II mRNA are both abundant within adipose tissue, an up-regulation of their receptor mRNA can promote adipose tissue deposition (Bispham et al. 2003b). It is likely that fat growth may be further enhanced after birth, particularly following a period of excess nutrient availability.

Stimulatory effects of maternal undernutrition in early gestation on mRNA abundance in adipose tissue during late gestation are not confined to IGF receptors, but extend to the glucocorticoid receptor and the enzyme 11ß-hydroxysteroid dehydrogenase type 1 (Whorwood et al. 2001). This enzyme acts predominantly as an 11-oxoreductase catalysing the conversion of cortisone to bio-active cortisol (Bamberger et al. 1996; Stewart \& Krozowski, 1999). Transgenic mice in which $11 \beta$-hydroxysteroid dehydrogenase type 1 is over expressed show substantially increased visceral adipose tissue deposition at 18 weeks of age (Masuzaki et al. 2001). The extent to which altered abundance of mRNA for IGF-I or -II receptors may be mediated by an increased sensitivity and/or production of cortisol within adipocytes of nutrient-restricted offspring remains to be confirmed.

\section{Maternal nutrient intake in late gestation and the programming of fetal leptin sensitivity}

Plasma leptin is normally low in the late-gestation ovine fetus and does not respond to decreased maternal nutrition over the final month of gestation (Yuen et al. 2002). It has been shown to be positively correlated with both body weight and leptin mRNA abundance in perirenal adipose tissue in some (Yuen et al. 1999; Bispham et al. 2002), but not all (Devasker et al. 2002), studies to date. In the fetus leptin may act as a signal of unilocular fat mass when maternal nutrient intake is fixed at or above maintenance (Mulhlauser et al. 2002). A primary factor that could determine this relationship may be the prevailing plasma leptin concentration in conjunction with fat mass, as in the latter study plasma leptin was found to be much higher than in all other studies to date, i.e. 2-9 ng/ml (Mulhlauser et al. 2002) compared with 1-1.5 ng/ml (Bispham et al. 2002; Yuen et al. 2002). Moreover, in growth-restricted fetuses that are hypoglycaemic with very low adipose tissue stores fetal plasma leptin is similarly reduced (Forhead et al. 2002; Fig. 3).

The abundance of leptin mRNA in fetal adipose tissue can be markedly suppressed by increased nutrition, when the mother is fed to appetite in late gestation (Bispham et al. $2003 b$ ). Any extra available energy may be used to promote 


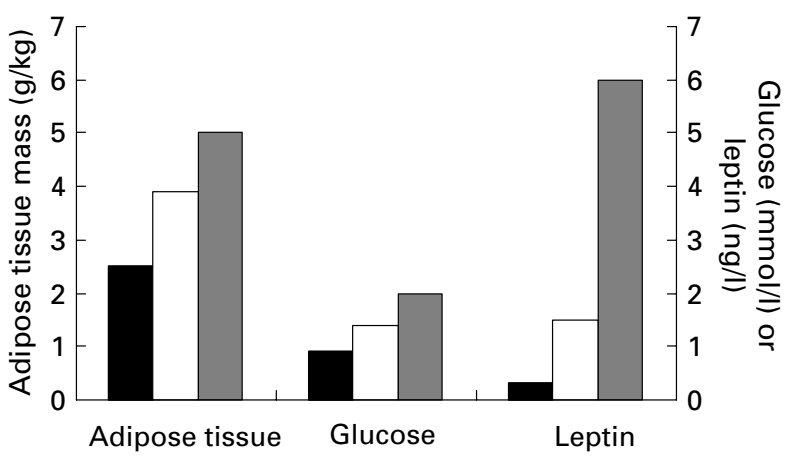

Fig. 3. Relationship between fetal adipose tissue mass near to term with the prevailing fetal plasma glucose and leptin concentrations. The level of maternal food intake (i.e. $50 \%$ (口); $100 \%(\square)$; $150 \%(\square)$ ) relates to the total estimated metabolisable energy requirements for the final month of gestation. (Adapted from Forhead et al. 2002, Mulhlauser et al. 2002 and Yuen et al. 2002.)

the growth of fetal tissues other than adipose tissue, which has a much greater energetic requirement. Other potential roles for leptin in the fetus remain to be established, although it is interesting to note that intracerebroventricular infusion of leptin into hypoleptinaemic fetuses dampens the increase in fetal corticotropin and cortisol pulses near to term (Howe et al. 2002). The fetus, however, has no direct regulation of food intake and its growth is limited by nutrient availability, with increased nutrition promoting somatotrophic growth rather than fat deposition. It has yet to be investigated whether a reduction in leptin secretion from fetal adipose tissue would potentially benefit the fetus at a time when nutrient supply is not limited.

\section{Maternal nutritional manipulation in late gestation}

Manipulation of both the maternal metabolic and hormonal environment as a consequence of increasing or decreasing food intake in late gestation can act to reduce adipose tissue deposition in the resulting offspring (Symonds et al. 2003). Maternal energy restriction in late gestation, coincident with the period of maximal fetal growth and a parallel rise in fetal fat depots, results in reduced adiposity if this energy restriction is accompanied by a reduction in fetal glucose supply (Symonds et al. 1998). This adaptation in nutrientrestricted mothers can be overcome by chronic maternal adaptations that accompany cold exposure (Symonds et al. 1992), thereby increasing fetal plasma glucose concentration (Thompson et al. 1982) and promoting fat deposition. As a consequence these offspring are better adapted to meet the cold challenge of the extrauterine environment as a result of an increased total thermogenic capacity within brown adipose tissue (Symonds et al. 1992). A similar overall adaptation can occur by increasing maternal food intake in late gestation (Budge et al. 2000). However, although this adaptation promotes fetal growth and total UCP1 abundance, the fetus possesses less fat when expressed in either absolute terms or relative to body weight. These divergent responses emphasise the complex control of nutrient partitioning within fetal adipose tissue.
Fetal number and adipose tissue sensitivity

A further determinant of the outcome of any nutritional manipulation in late gestation is fetal number (Budge et al. 2003). Nutrient restriction of twin fetuses causes an upregulation of specific mitochondrial proteins within fetal adipose tissue, an adaptation that is not found in singletons. The abundance of both voltage-dependent anion channel and UCP2 are enhanced (Budge et al. 2003; Mostyn et al. 2003). These adaptations within the mitochondria are predicted to substantially alter adipocyte function. Voltagedependent anion channel and UCP2 are both implicated in the regulation of the rate of apoptosis and necrosis (Crompton, 1999; Voehringer et al. 2000) as well as in regulating the supply of mitochondrial ATP and ADP (Gottlieb, 2000). One potential mechanism related to the increased sensitivity of adipose tissue of twins compared with singletons following maternal undernutrition may relate to the relative abundance of the prolactin receptor (Budge et al. 2003), which is greater in the adipose tissue of twins than in that of singletons irrespective of nutritional status. Twins subsequently go on to deposit more fat over the first month of postnatal life (Pearce et al. 2002). In fetal fat there is a marked developmental ontogeny for the prolactin receptor, which may act to determine the abundance of specific mitochondrial proteins (Symonds et al. 1998). Support for this proposal comes from the finding that increased maternal nutrition not only stimulates UCP1 abundance but also promotes protein abundance of the long form of the prolactin receptor (Budge et al. 2000). It is likely, therefore, that an increase in fetal plasma prolactin in late gestation specifically promotes UCP1 mRNA expression and protein translation (Budge et al. 2002).

The positive effects of maternal nutritional manipulation on mitochondrial protein abundance are not restricted to the period immediately after birth but extend into postnatal life. Offspring of energy-restricted mothers possess adipose tissue (and lungs) in which the abundance of both voltagedependent anion channel and UCP2 remain raised at 1 month of age (Mostyn et al. 2003). A higher abundance of UCP2 may have deleterious consequences in relation to later development, as a reduced abundance of UCP2 increases resistance to infection from, for example, toxoplasmosis (Arsenijevic et al. 2000). It has also been shown that in obese women $U C P 2$ gene exon 8 may affect susceptibility to obesity through an interaction with leptin (Cassell et al. 1999). Enhanced abundance of both UCP2 and voltage-dependent anion channel could result in an accelerated rate of apoptosis (Voehringer et al. 2000) and greater predisposal to adult disease, as a consequence of chronic impairment in lung function together with excess fat deposition. Epidemiological studies have indicated that nutrient restriction of pregnant women can predispose the resulting offspring to obesity or chronic lung disease in adulthood (Barker et al. 1991; Roseboom et al. 2000a), although it remains to be established if these two adaptations are linked. The findings in sheep indicate that the development of adipose tissue mitochondria can be reprogrammed in late gestation and may be an important mechanism by which infants of nutrient-restricted mothers could subsequently become obese. 

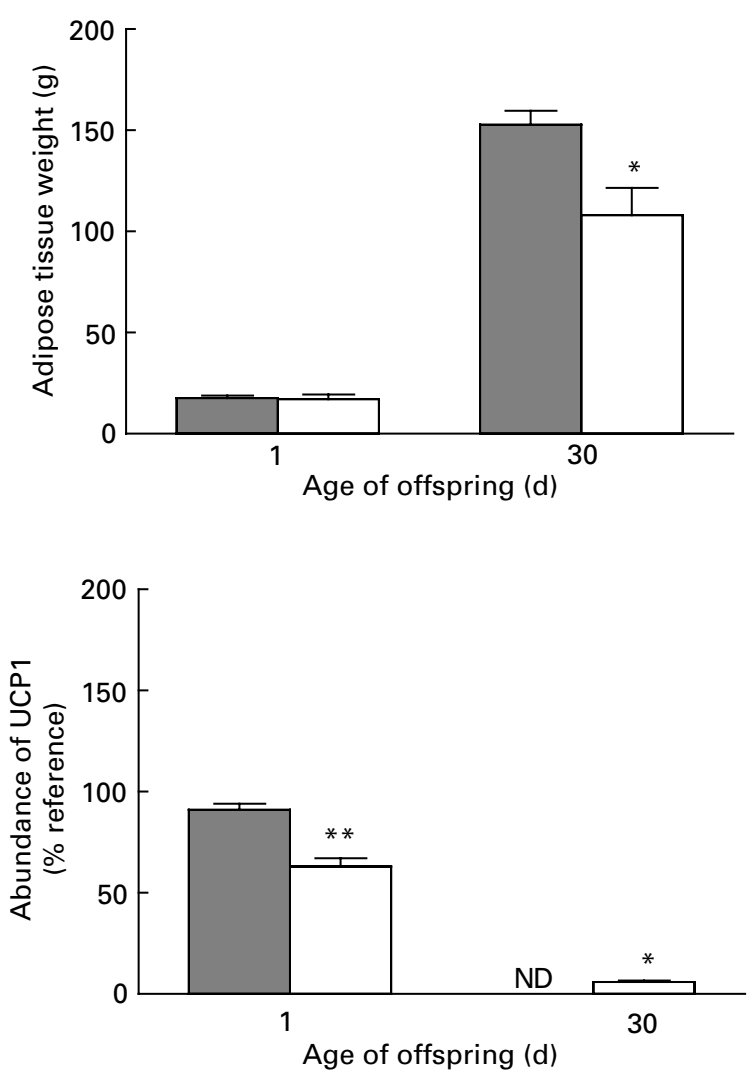

Fig. 4. Influence of maternal parity on perirenal adipose tissue mass and uncoupling protein (UCP) 1 abundance at 1 month of age. ( $\square$ ), Primiparous; ( $\square$ ), multiparous. Values are means with their standard errors represented by vertical bars. ND, not detected. Mean values were significantly different from those for the offspring of primiparous mothers: ${ }^{*} P<0.05,{ }^{* *} P<0.01$. (Adapted from Pearce et al. 2003.)

\section{Maternal age as a determinant of adiposity in the resulting offspring}

It is recognised that birth weight normally increases with parity, even when maternal body weight has changed very little between the first and second pregnancies. This adaptation is apparent in sheep, independent of whether the ewe has a singleton or twin pregnancy (Symonds et al. 2004). The increase in birth weight with parity can, however, be compromised by previous nutrient restriction during pregnancy. For example, females born to mothers exposed to the Dutch famine in early gestation have further shown a decline in birth weight by $250-350 \mathrm{~g}$ with increasing parity. A decline in birth weight between the first and subsequent pregnancies contrasts with the expected rise in birth weight with increasing birth order found in women not exposed to famine or exposed to famine in later pregnancy (Lumey \& Stein, 1997). To date, there have been no studies that have directly compared the body composition, tissue endocrine sensitivity or subsequent growth and development of the offspring as a consequence of increased maternal parity. This information may have substantial implications for contemporary populations even when adequate nutrition is available, given the substantial decline in birth rates within the UK and Europe. It is now the norm for many women

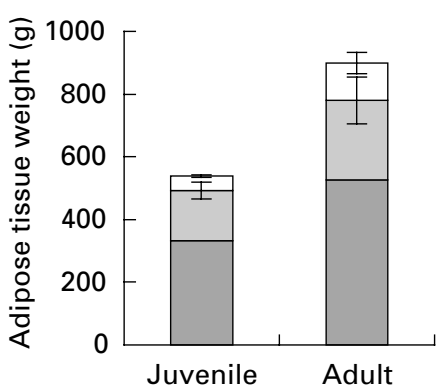

Fig. 5. Effect of maternal age on adipose tissue deposition in the resulting offspring at 1 year of age. ( $\square$ ), Pericardial; $(\square)$, perirenal and abdominal; $(\square)$, omental. Values are means with their standard errors represented by vertical bars.

to have only one child. It is possible, therefore, that in addition to the pronounced impact that contemporary lifestyles have on increased prevalence of childhood obesity and diabetes, being born from a first pregnancy may also be an additional risk factor. The percentage of the UK population for which this situation is relevant is now far greater than that used for the majority of epidemiological studies that have involved individuals born 50-60 years ago.

It has recently been found that the offspring of primiparous mothers deposit appreciable more adipose tissue than those born to multiparous mothers (Pearce et al. 2003; Fig. 4). Critically, these effects are observed despite similar growth rates, and are therefore apparent whether tissue weights are expressed in absolute terms or relative to current body weight. Similar effects are not found in the other major organs, including the brain and heart. Maternal parity is, therefore, a major factor determining subsequent adiposity, although the extent to which this factor may have deleterious longer-term consequences has yet to be established. The enhanced adiposity in offspring of primiparous mothers is accompanied by accelerated loss of the brown adipose tissue-specific UCP1. A suppressed rate of metabolism within brown fat of these offspring may act to promote adipose tissue deposition in later life. It has been established that transgenic mice lacking UCP1 subsequently go on to develop obesity (Lowell et al. 1993), but the extent to which obesity may be prevented by enhanced UCP1 abundance in early life has been overlooked. One explanation for this oversight has been that small mammals, unlike sheep and man (Lean, 1989; Mostyn et al. 2003), always retain brown adipose tissue through their life cycle, which is likely to have profound effects on fat metabolism, and hence its growth.

The critical importance that maternal age as well as first pregnancy may play in relation to adipose tissue growth in the resulting offspring is further emphasised by studies comparing fat deposition in sheep born to juvenile or adult mothers. These studies have demonstrated that one factor that may be protective in terms of subsequent adiposity is maternal age. In 1-year-old sheep the offspring of juvenile mothers have substantially reduced fat deposition compared with those born to adult mothers (Fig. 5). The weights of all other major organs (e.g. liver, kidney, heart) are unaffected by maternal age. 


\section{Conclusion}

The amount, metabolic activity and endocrine sensitivity of adipose tissue are highly dependent on the maternal nutritional, metabolic and hormonal environment. Intervention strategies aimed at these critical periods of development are very likely to reduce an individual's predisposal to obesity in adult life. Given the annual increase in the incidence of obesity within Europe and the USA, this approach would contribute to substantial improvements in health and economic performance.

\section{References}

Arsenijevic D, Onuma H, Pecquer C, Raimbault S, Manning BS, Miroux B, Couplan E, Alves-Guerra M-C, Goubern M, Surwit R, Bouillaud F, Richard D, Collins S \& Ricquier D (2000) Disruption of the uncoupling protein-2 gene in mice reveals a role in immunity and reactive oxygen species production. Nature Genetics 26, 435-439.

Bamberger CM, Schulte HM \& Chrousos GP (1996) Molecular determinants of glucocorticoid receptor function and tissue sensitivity to glucocorticoids. Endocrinology Reviews 17, 245-261.

Barker DJP, Godfrey KM, Fall C, Osmond C, Winter PD \& Shaheen SO (1991) Relation of birth weight and childhood respiratory infection to adult lung function and disease from obstructive airways disease. British Medical Journal 303, 671-675.

Bispham J, Budge H, Mostyn A, Dandrea J, Clarke L, Keisler D, Symonds ME \& Stephenson T (2002) Ambient temperature, maternal dexamethasone, and postnatal ontogeny of leptin in the neonatal lamb. Pediatric Research 52, 85-90.

Bispham J, Clarke L, Symonds ME \& Stephenson T (2003a) Postnatal ontogeny of insulin-like growth factor (IGF) and prolactin receptor (PRL-R) in ovine perirenal adipose tissue. Journal of Physiology (London) 547P, C65.

Bispham J, Gopalakrishnan GS, Dandrea J, Wilson V, Budge H, Keisler DH, Broughton Pipkin F, Stephenson T \& Symonds ME (2003b) Maternal endocrine adaptation throughout pregnancy to nutritional manipulation: consequences for maternal plasma leptin and cortisol and the programming of fetal adipose tissue development. Endocrinology 144, 3575-3585.

Budge H, Bispham J, Dandrea J, Evans L, Heasman L, Ingleton P, Sullivan C, Wilson V, Stephenson T \& Symonds ME (2000) Effect of maternal nutrition on brown adipose tissue and prolactin receptor status in the fetal lamb. Pediatric Research 47, 781-786.

Budge H, Dandrea J, Mostyn A, Evens Y, Watkins R, Sullivan C, Ingleton P, Stephenson T \& Symonds ME (2003) Differential effects of fetal number and maternal nutrition in late gestation on prolactin receptor abundance and adipose tissue development in the neonatal lamb. Pediatric Research 53, 302-308.

Budge H, Edwards LJ, McMillen IC, Bryce A, Warnes K, Stephenson T \& Symonds ME (2004) Nutritional manipulation of fetal adipose tissue deposition and uncoupling protein 1 abundance in the fetal sheep; differential effects of timing and duration. Biology of Reproduction (In the Press).

Budge H, Mostyn A, Wilson V, Khong A, Walker AM, Symonds ME \& Stephenson T (2002) The effect of maternal prolactin infusion during pregnancy on fetal adipose tissue development. Journal of Endocrinology 147, 427-433.

Cassell PG, Neverova M, Janmohamed S, Uwakwe N, Qureshi A, McCarthy MI, Saker PJ, Albon L, Kopelman P, Noonan K, Easlick J, Ramachandran A, Snehalatha C, Pecqueur C, Ricquier D, Warden C \& Hitman GA (1999) An uncoupling protein 2 gene variant is associated with a raised body mass index but not type II diabetes. Diabetologia 42, 688-692.

Clarke L, Bryant MJ, Lomax MA \& Symonds ME (1997a) Maternal manipulation of brown adipose tissue and liver development in the ovine fetus during late gestation. British Journal of Nutrition 77, 871-883.

Clarke L, Buss DS, Juniper DS, Lomax MA \& Symonds ME (1997b) Adipose tissue development during early postnatal life in ewe-reared lambs. Experimental Physiology 82, 1015-1017.

Crompton M (1999) The mitochondrial permeability transition pore and its role in cell death. Biochemical Journal 341, 233-249.

Dandrea J, Wilson V, Gopalakrishnan G, Heasman L, Budge H, Stephenson T \& Symonds ME (2001) Maternal nutritional manipulation of placental growth and glucose transporter-1 abundance in sheep. Reproduction 122, 793-800.

Devasker SU, Anthony RV \& Hay WW (2002) Ontogeny and insulin regulation of fetal ovine white adipose tissue leptin expression. American Journal of Physiology 282, R431-R438.

Forhead AJ, Thomas L, Crabtree J, Hoggard N, Gardner DS, Giussani DA \& Fowden AL (2002) Plasma leptin concentrations in fetal sheep during late gestation: ontogeny and effect of glucocorticoids. Endocrinology 275, 1166-1173.

Gemmel RT, Bell AW \& Alexander G (1972) Morphology of adipose cells in lambs at birth and during subsequent transition of brown to white adipose tissue in cold and in warm conditions. American Journal of Anatomy 133, 143-164.

Godfrey K, Robinson S, Barker DJP, Osmond C \& Cox V (1996) Maternal nutrition in early and late pregnancy in relation to placental and fetal growth. British Medical Journal 312, 410-414.

Gopalakrishnan G, Rhind SM, Stephenson T, Kyle CE, Brooks AN, Rae MT \& Symonds ME (2001) Effect of maternal nutrient restriction at defined periods in early to mid gestation on placento-fetal, kidney and adipose tissue weights at 110 days gestation in sheep. Early Human Development 63, 58-59.

Gottlieb RA (2000) Mitochondria: execution central. FEBS Letters 482, 6-12.

Heasman L, Brameld JM, Mostyn A, Budge H, Dawson J, Buttery PJ, Stephenson T \& Symonds ME (2000) Maternal nutrient restriction during early to mid gestation alters the relationship between IGF-I and body size at term in fetal sheep. Reproduction, Fertility and Development 12, 345-350.

Howe DC, Gertler A \& Challis JRG (2002) The late gestation increase in circulating ACTH and cortisol in the fetal sheep is suppressed by intracerebroventricular infusion of recombinant ovine leptin. Journal of Endocrinology 170, 259-266.

Lean MEJ (1989) Brown adipose tissue in humans. Proceedings of the Nutrition Society 48, 243-256.

Lorenzo M, Valverde AM, Teurel T \& Benito M (1993) IGF-I is a mitogen involved in differentiation-related gene expression in fetal brown adipocytes. Journal of Cell Biology 123, 15671575.

Lowell BB, S-Susulic V, Hamann A, Lawitts JA, Himms-Hagen J, Boyer BB, Kozak LP \& Flier JS (1993) Development of obesity in transgenenic mice after genetic ablation of brown adipose tissue. Nature 366, 740-742.

Lumey LH \& Stein AD (1997) Offspring birthweights after maternal intrauterine undernutrition: a comparison within sibships. American Journal of Epidemiology 146, 810-819.

Masuzaki H, Paterson J, Shinyama H, Morton NM, Mullins JJ, Seckl JR \& Flier JS (2001) A transgenic model of visceral obesity and the metabolic syndrome. Science 294, 2166-2170.

Mostyn A, Wilson V, Dandrea J, Yakubu DP, Budge H, AlvesGuerra MC, Pecqueur C, Miroux B, Symonds ME \& Stephenson T (2003) Ontogeny and nutritional manipulation of mitochondrial protein abundance in adipose tissue and the 
lungs of postnatal sheep. British Journal of Nutrition 90, 323-328.

Moulin K, Truel N, Andre M, Arnauld E, Nibbelink M, Cousin B, Dani C, Penicaud L \& Casteilla L (2001) Emergence during development of the white-adipocyte cell phenotype is independent of the brown-adipocyte cell phenotype. Biochemical Journal 356, 659-664.

Mulhlauser BS, Roberts CT, McFarlane J, Kauter KG \& McMillen IC (2002) Fetal leptin is a signal of fat mass independent of maternal nutrition in ewes fed at or above maintenance energy requirements. Biology of Reproduction 67, 493-499.

Owens JA, Kind KL, Carbone F, Robinson JS \& Owens PC (1994) Circulating insulin-like growth factors-I and -II and substrates in fetal sheep following restriction of placental growth. Journal of Endocrinology 140, 5-13.

Pearce S, Dandrea J, Symonds ME \& Stephenson T (2002) Comparison of adipose tissue and organ deposition between singleton and twin lambs at one month of age. Proceedings of the Nutrition Society 61, 132A.

Pearce S, Wang J, Symonds ME \& Stephenson T (2003) Effect of maternal parity on adipose tissue development in the resulting offspring. Pediatric Research 53, Suppl. 40A

Roseboom TJ (2000) Prenatal exposure to the Dutch famine and health in later life. PhD Thesis, University of Amsterdam, The Netherlands.

Roseboom TJ, van der Meulen JHP, Osmond C, Barker DJP, Ravelli ACJ \& Blecker OP (2000a) Plasma lipid profile in adults after perinatal exposure to famine. American Journal of Clinical Nutrition 72, 1101-1106.

Roseboom TJ, van der Meulen JHP, Osmond C, Barker DJP, Ravelli ACJ, Schroeder-Tanka JM, von Montfrans GA, Michels RPJ \& Blecker OP (2000b) Coronary heart disease in adults after perinatal exposure to the Dutch famine, 1944-45. Heart 84, 595-598.

Stevens D, Alexander G \& Bell AW (1990) Effects of prolonged glucose infusion into fetal sheep on body growth, fat deposition and gestation length. Journal of Developmental Physiology 13, 277-281.

Stewart PM \& Krozowski ZS (1999) 11ß-Hydroxysteroid dehydrogenase. Vitamins and Hormones 57, 249-324.

Symonds ME, Bryant MJ, Clarke L, Darby CJ \& Lomax MA (1992) Effect of maternal cold exposure on brown adipose tissue and thermoregenesis in the neonatal lamb. Journal of Physiology (London) 455, 487-502.

Symonds ME, Gardner DS, Pearce S \& Stephenson T (2004) Endocrine responses to fetal undernutrition: the growth hormone (GH): insulin-like growth factor (IGF) axis. In Fetal Nutrition and Adult Disease - Programming of Chronic Disease Through Fetal Exposure to Undernutrition, pp. 353-380 [SC Langley-Evans, editor]. Wallingford, Oxon.: $\mathrm{CAB}$ International.
Symonds ME \& Lomax MA (1992) Maternal and environmental influences on thermoregulation in the neonate. Proceedings of the Nutrition Society 51, 165-172.

Symonds ME, Mostyn A, Pearce S, Budge H \& Stephenson T (2003) Energy regulation in the fetus: endocrine control of adipose tissue development. Journal of Endocrinology 179, 293-299.

Symonds ME, Phillips ID, Anthony RV, Owens JA \& McMillen IC (1998) Prolactin receptor gene expression and foetal adipose tissue. Journal of Neuroendocrinology 10, 885-890.

Symonds ME \& Stephenson T (1999) Maternal nutrient restriction and endocrine programming of fetal adipose tissue development. Biochemical Society Transactions 27, 97-103.

Teruel T, Valverde AM, Benito M \& Lorenzo M (1996) Insulinlike growth factor and insulin induce adipogenic-related gene expression in fetal brown adipocyte primary cultures. Biochemical Journal 319, 627-632.

Thompson GE, Bassett JM, Samson DE \& Slee J (1982) The effect of cold exposure of pregnant sheep on fetal plasma nutrients, hormones and birth weight. British Journal of Nutrition 48, 59-64.

Voehringer DW, Hirschberg DL, Xiao J, Lu Q, Roederer M, Lock CB, Herzenberg LA, Steinman L \& Herzenberg LA (2000) Gene microarray identification of redox and mitochondrial elements that control resistance or sensitivity to apoptosis. Proceedings of the National Academy of Sciences USA 97, 2680-2685.

Whorwood CB, Firth KM, Budge H \& Symonds ME (2001) Maternal undernutrition during early- to mid-gestation programmes tissue-specific alterations in the expression of the glucocorticoid receptor, 11ß-hydroxysteroid dehydrogenase isoforms and type 1 angiotensin II receptor in neonatal sheep. Endocrinology 142, 1778-1785.

Young L, Fernandes K, McEvoy T, Butterwith S, Gutierrez C, Carolan C, Broadbent P, Robinson J, Wilmut I \& Sinclair K (2001) Epigenetic change in IGF2R is associated with fetal overgrowth after embryo culture. Nature Genetics 27, 153-154.

Yuen BS, Owens PC, Muhlhausler BS, Roberts CT, Symonds ME, Keisler DH, McFarlane JR, Kauter KG, Evens Y \& McMillen IC (2003) Leptin alters the structural and functional characteristics of adipose tissue before birth. FASEB Journal 17, 1102-1104.

Yuen BSJ, McMillen IC, Symonds ME \& Owens PC (1999) Abundance of leptin messenger ribonucleic acid in fetal adipose tissue is related to fetal body weight. Journal of Endocrinology 163, R1-R4.

Yuen BSJ, Owens PC, McFarlane J, Symonds ME, Edwards LJ, Kauter KG \& McMillen IC (2002) Circulating leptin concentrations are positively related to leptin mRNA expression in fetus adipose tissue in the pregnant ewe fed at or below maintenance energy requirements during late gestation. Biology of Reproduction 67, 911-916. 
https://doi.org/10.1079/PNS2004366 Published online by Cambridge University Press 